\title{
NANOSILICA FROM THE BOILER ASH OF THE SUGAR CANE INDUSTRY AS A FILLER OF POLYSULFONE AND SULFONATED POLYETHERETHERKETONE MEMBRANES IN DIRECT METHANOL FUEL CELL
}

\section{NANOSILIKA DARI ABU KETEL INDUSTRI GULA SEBAGAI PENGISI MEMBRAN POLISULFON DAN POLIETERETERKETON PADA DIRECT METHANOL FUEL CELL}

\author{
Andes Ismayana ${ }^{1)}$, Akhiruddin Maddu' ${ }^{2)}$, Yunia Istifani ${ }^{1)}$, Nastiti Siswi Indrasti1 ${ }^{1 *}$ \\ ${ }^{1)}$ Department of Agroindustrial Technology, Bogor Agricultural University, Bogor, Indonesia \\ ${ }^{2)}$ Department of Physics, Bogor Agriculural University, Bogor, Indonesia \\ Email: nastiti.indrasti@gmail.com
}

Makalah: Diterima 21 November 2017; Diperbaiki 8 Maret 2018; Disetujui 25 Maret 2018

\begin{abstract}
ABSTRAK
Nanosilika dari abu ketel industri gula tebu dapat digunakan sebagai pengisi untuk komposit polimer PSF-sPEEK untuk menjadi membran alternatif pada DMFC yang selama ini menggunakan membran elektrolit Politetrafloroetilena (PTFE). Membran PTFE tersebut memiliki harga tinggi, methanol crossover tinggi, stabilitas rendah pada suhu tinggi, dan konduktivitas rendah pada kelembaban rendah atau suhu tinggi. Tujuan penelitian ini adalah untuk menentukan pengaruh dari komposisi perbandingan polisulfon (PSF)polietereterketon tersulfonasi (sPEEK) dan perbandingan campuran polimer tersebut dengan penambahan nanosilika terhadap kinerja membran. Penelitan ini dilakukan melalui sintesis nanosilika dari abu ketel dengan metode ektraksi basa dan proses presipitasi, serta penambahan nanosilika tersebut terhadap komposit PSFsPEEK untuk membentuk membran elektrolit melalui metode inversi fasa. Komposisi perbandingan PSF-sPEEK yaitu 1:9; 1:12; 1:15 sedangkan penambahan nanosilika yaitu sebanyak 1\%, 3\% dan 5\%. Nanosilika yang dihasilkan memiliki ukuran partikel $330 \mathrm{~nm}, \mathrm{PDI}$ (polydispersity index) 0.3, ukuran kristal 47,49 nm, dan derajat kristalinitas 64\%. Uji ANOVA menunjukkan bahwa penambahan nanosilika dan komposisi PSF-sPEEK berpengaruh nyata terhadap kinerja membran. Membran dengan komposisi 1:12 dengan penambahan nanosilika 3\% memiliki kinerja lebih baik dibandingkan membran yang lainnya dengan nilai daya serap air, daya serap methanol, kapasitas penukar ion dan konduktivitas ionic berturut-turut 27,21\%, 25,62\%, 2,56 meq/g, dan $66,28 \times 10^{-6} \mathrm{~S} / \mathrm{cm}$.
\end{abstract}

Kata kunci: membran DMFC, nanosilika, PSF (polisulfon), sPEEK (polieter-eterketontersulfonasi).

\begin{abstract}
Nanosilicafrom the boiler ash of the sugarcane industry can be utilizedas a filler for the composite polymer of polysulfone (PSF)-sulfonated polyetheretherketone (sPEEK), to become an alternative membrane in DMFC which has been using Polytetraflouroethylene (PTFE) electrolyte membranes. PTFE membrane in DMFC has characteristics of high cost, high methanol crossover, low stability at high temperature, and low conductivity at low humidity or at high temperature. The objective of this research was todetermine the influence of composition of PSF-sPEEK and the ratio of such polymers with the addition of nanosilicas to the performance of the membrane. This research was conducted through the synthesis of nanosilica from boiler ash by alkaline extraction method and precipitation process, and the addition of nanosilica to the blending of PSF-sPEEK composite for electrolyte membrane through phase inversion method. The compositionratio ofPSF:sPEEK were $1: 9 ; 1: 12 ; 1: 15$, while the various concentration of nano silicawere $1 \%, 3 \%$ and $5 \%$. The characteristics of nanosilica wereparticle size of $330 \mathrm{~nm}$, PDI (polydispersity index) of 0.3 , degree of crystallinity of $64 \%$, and crystal size of $47.49 \mathrm{~nm}$. Analysis of variance showed that the addition ofnanosilica and the blending of PSFsPEEK gave the significant effect to the membrane performance. Membrane with PSF:sPEEK ratio of 1:12 and addition of 3\% nano silicawas the best composition with the value of water absorption, methanol absorption, ion exchange capacity, and ionic conductivity of $27.21 \%, 25.62 \%, 2.56 \mathrm{meq} / \mathrm{g}$, and $66.28 \times 10^{-6} \mathrm{~S} / \mathrm{cm}$, respectively.
\end{abstract}

Keywords: DMFC membrane, nanosilica, polysulfone), sulfonated polyetheretherketone

\section{INTRODUCTION}

Boiler ash is a by-product of sugarcane industry from combustion process of bagasse on the boiler equipment. One of the most inorganic mineral content of boiler ash was silica compound which an average content of $46.96 \%$ (Ismayanaet al., 2017) with a maximum value of 70.97\% (Qistiet al., 2017). Silica particles should be formed into nano-sized particles, called nanosilica to extensive their utilization. Utilization of nanosilika could be improved the properties and characteristics, depending on the need to support the performance of the application. Nanosilica had good stability, inert, 
and biocompatible as a filler material (Windiastuti et al., 2016). One application of nanosilika was as a filler for electrolyte membrane fordirectmethanol fuelcell (DMFC). The addition of nanosilica should increase the conductivity of proton membranes (Setiawan, 2015). The nanosilicas used as DMFC membrane fillers had characteristics of nano-sized particles, were amorphous, and had a PDI (Polidispersity Index) of less than 0.7 (Hartanto et al., 2007; Utomo, 2015; Setiawan et al., 2015).

The electrolyte membrane was an important component in the DMFC system which functionate as a separator between reactants and as a proton transfer medium from the anode to the cathode in order that the cathode reaction should produce electrical energy (Carettelet al., 2001; Bossel, 2000). The performance of the DMFC membrane could be seen from several parameters, such as ionic conductivity and methanol permeability. The higher ion conductivity caused the better of membrane performance. Decreased methanol permeability should improve the membrane performance. One way to increase membrane performance was by modifying the membrane structure and adding a filler to the membrane (Hartanto et al., 2007).

Presently the most common membrane used for DMFC was polytetrafluoroethylene (PTFE) which known as Nafion (Dupont, 1996). The PTFE membrane had a good characteristic as an electrolyte membrane such as high methanol crossover, low stability at high temperatures, and low conductivity at low humidity or high temperature, but nevertheless had a high price. Therefore several studies had been conducted to substitute the PTFE membrane as an alternative membrane on DMFC. Hartanto et al. (2007) had modified the polyetheretherketone (PEEK) polymer, but the use of PEEK as a membrane material had a weakness that the ion conductivity was lower than Nafion. One modification that could be done to increase the characteristics of the PEEK membrane was to add a filler. In addition to PEEK, polysulfone (PSF) is also a potential material used as an electrolyte membrane. Polysulfone is a thermoplastic hydrophobic polymer up to $190^{\circ} \mathrm{C}$ of temperature (Juniarzadinata, 2011).

Both materials (PEEK - PSF) could be blended as a DMFC membrane material, and was expected to increase membrane characteristics. This was in accordance with previous research from Hartanto et al. (2007), which obtained a membrane from the blend of sPEEK-PSF at a ratio of 9: 1, however still had lower methanol permeability than the Nafion membrane. The addition of fillers such as nanosilica to the PSF-sPEEK blend was expected to improve the membrane performance so that the membrane could be used as an alternative membrane of Nafion (PTFE) with better characteristics. The objective of this research was to determine the influences of addition of the nanosilica and blend composition of PSF-sPEEK to DMFC membrane performance.

\section{MATERIAL AND METHODS}

\section{Materials and Equipments}

The materials used in this research were boiler ash, PEEK, PSF 26000, $\mathrm{NaOH}$, distilled water, $\mathrm{H}_{2} \mathrm{SO}_{4}, \mathrm{HCl}, \mathrm{NH}_{4} \mathrm{OH}$, and n-methyl-2pyrrolidone.The equipments used in this research were glass equipment, furnaces, reflux appliances. Analysis equipments includes anX-Ray Fluorescence (XRF) ARL OPTX-2050 Analyzer, a Vasco Particle Size Analyzer (PSA), an Emma GBCX-Ray Diffraction (XRD), an Fourier Transform Infrared (FTIR), and a HIOKI 3532LCRmeter.

\section{Synthesis of Nanosilica from Boiler Ash}

Boiler ashwas screenedwith mesh filter and burnt at temperature of $700^{\circ} \mathrm{C}$ for 6 hours using a furnace equipment (Thuadaij dan Nuntiya, 2008), and produced furnace ash. Ten grams of furnace ashwas extracted using $80 \mathrm{~mL}$ of $2,5 \mathrm{~N} \mathrm{NaOH}$ for 3 hours. The solution was filtered by Whatmaan paper and the residue was washed with $20 \mathrm{~mL}$ of boiling distilled water. The filtrate was allowed to cool down at room temperature. The filtrate was titrated with $5 \mathrm{~N} \mathrm{H}_{2} \mathrm{SO}_{4}$ until $\mathrm{pH} 2$. Afterward, it was titrated with $2.5 \mathrm{~N} \mathrm{NH}_{4} \mathrm{OH}$ until $\mathrm{pH}$ 8.5. The solution was aged at room temperature for 3.5 hours, then dried at $105^{\circ} \mathrm{C}$ for 12 hours to obtain drysilica (Thuadaij and Nuntiya, 2008; Ismayana et al., 2017). Silica was hydrolyzed with $3 \mathrm{~N} \mathrm{HCl}$ for 6 hours. Then, the solution was filtered and the residue was washed with distilled water to netral $\mathrm{pH}$. Furthermore, the residue was dissolved in $\mathrm{NaOH} 2,5 \mathrm{~N}$. The homogen solutionwas added $5 \mathrm{~N} \mathrm{H}_{2} \mathrm{SO}_{4}$ to $\mathrm{pH} 7$. The solution aged at room temperature for 3 hours, then washed with boiling water and dried at $105^{\circ} \mathrm{C}$ for 12 hours (Thuadaij and Nuntiya, 2008; Setiawan et al., 2015; Utomo, 2015; Ismayana et al., 2017).

\section{Sulfonation of PEEK}

First, sulfonation of PEEKwas carried out by dissolving PEEK in concentrated sulfuric acid $\mathrm{H}_{2} \mathrm{SO}_{4} \quad(95-97 \%)$ with a ratio $(1: 20 \mathrm{w} / \mathrm{v})$ at temperature of $50^{\circ} \mathrm{C}$ while it wasstirred for 3 hours. Sulfonation reaction was stopped by entering the polymer solution into the ice water to form solid polymer and left it overnight. The precipitated polymer was filtered andwashed several times with distilled water untilit reached neutral $\mathrm{pH}$. The sPEEK was dried at $60^{\circ} \mathrm{C}$ for 28 hours (Hartanto et al., 2007; Handayani et al., 2007).

\section{Synthesis of Membrane}

Membrane was carried out by phase inversion method. Poliymerof PSF and sPEEK was dissolved in n-methyl-2-pyrrolidoneand stirred until homogen 
for 6 hours. The ratio of PSF:sPEEK were 1:9; 1:12; $1: 15$. After the mixture came into soluble stage, nanosilica was added with various concentration of $1 \%, 3 \%$ and $5 \%$. The mixture of membrane materials was called dope solution. The dope solution was ultrasonicated for 30 minutes. Finally, the dope solution was casted on glass plate and dried at $40^{\circ} \mathrm{C}$ to vaporize the solvent.The experimental unit was done with 3 repetitions.

\section{Characterization Test}

\section{Boiler Ash Characterization}

The minerals contained in boiler ash and furnace ash were identified using the ARL OPTX$2050 \mathrm{XRF}$ operated at $10 \mathrm{~mA}$ and $50 \mathrm{kV}$. Five grams of sample were scanned and calibrated based on their energy intensity. The elements from $\mathrm{Na}$ to $\mathrm{U}$ were analyzed with Sintilation detector.

\section{Nanosilica Characterization}

Particle size and particle size distribution was observed using Vasco PSA. 0,002 grams of nanosilica was dispersed into distilled water. Then, the solution was stirred with magnetic stirrer for 10 minutes and sonicated for 1 minute. Nanosilica was scanned for 2-10 minutes.

The crystal size, crystallinity degree, crystal phase, and diffraction pattern was observed using EmmaGBC XRD operated at $35 \mathrm{kV}$ and $25 \mathrm{~mA}$. The Emma GBC XRD used $\mathrm{Cu}-\mathrm{K} \alpha$ with $\lambda=1.54 \AA$. Diffractogram was scanned at $10-60^{\circ}$ with scanning rate of $2^{\circ}$ per minute on room temperature. Crystalite size of nanosilica was calculated using Scherrer formula while the crystallinity degree was calculated by XRD-7000 software. The diffraction pattern and crystal phase was identified by fitting with Powder Diffraction File (PDF) card.

\section{Membrane Characterization \\ Sulfonation degree of SPEEK}

The sulfonation degree was determined by titration method. 0.1 grams of SPEEK was soaked in $10 \mathrm{~mL}$ of $1 \mathrm{~N} \mathrm{NaOH}$ for 3 days. Afterward, the solution was titrated using $0.1 \mathrm{~N} \mathrm{HCl}$ with 3 drops of phenolphtalein indicator. The sulfonation degree was calculated using the formula:

Degree of Sulfonation=

(Volume $\mathrm{HCl}$ blank-Volume $\mathrm{HCl}$ sample) weight of sample

\section{Water and Methanol Absorption}

A membrane measuring $1 \mathrm{~cm} \mathrm{x} 1 \mathrm{~cm}$ was dried in an oven and weighed as a dry membrane $\left(\mathrm{W}_{\mathrm{dry}}\right)$. Then membrane was soaked in water or $1 \mathrm{M}$ methanol for 24 hours. The sample was weighed as a wet membrane $\left(\mathrm{W}_{\text {wet }}\right)$ (Hartanto et al., 2007). Water absorption or methanol absorption was calculated using the formula:

$$
\text { Absorption }=\frac{(\text { Wwet-Wdry) }}{\text { Wdry }} \times 100 \%
$$

\section{Ion Exchange Capacity}

The ion exchange capacity (IEC) was identified by titration method. 0.25 grams of membrane was soaked in $50 \mathrm{ml}$ distilled water and stored in an oven for 1 hour and then added to it 0.5 $\mathrm{M} \mathrm{NaCl}$. The solution was stored for 24 hours at room temperature (Pramono et al., 2012). It was then titrated with $0.05 \mathrm{~N} \mathrm{NaOH}$ and $\mathrm{PP}$ indicator. The formula for IEC was determined to be

$$
\mathrm{IEC}=\frac{\mathrm{M} \mathrm{NaoH} \times \text { Volume } \mathrm{NaOH}}{\text { weight of membrane }}
$$

\section{Ion Conductivity}

A membrane measuring $4 \mathrm{~cm} \times 1 \mathrm{~cm}$ was clamped between two electrodes which were connected to the positive and negative poles of a HIOKI 3532LCR-meter. The value of its proton conductivity was calculated using the formula:

$$
\sigma=G \frac{L}{A}
$$

With $\sigma$ : proton conductivity $\left(\mathrm{S} . \mathrm{cm}^{-1}\right)$; D: membrane thickness (cm); G: conductance (S); A: area of electrode $\left(\mathrm{cm}^{2}\right)$. (Setiawan, 2015).

\section{Functional Group}

Membrane was located on testing paper cell holder of FTIR. Then the spectrum was observed using FTIR ABB 3000 with $\lambda$ range of 400-4000 nm and scanned with 10 time repetitions (Setiawan, 2015).

\section{RESULTS AND DISCUSSION}

\section{Nanosilica From Boilerash}

Boiler ash in this research contained Silica of $57.4 \%$ based on XRF analysis. The elements that contained in boiler ash were shown at Table 1.The boiler ashshould be transformedinto nanosilica using precipitation method with $\mathrm{pH}$ of 7 and aging time of 3 hours. Nanosilica as the result of precipitation method had the average particle size of $330 \mathrm{~nm}$ and PDI of 0.358 based on analysis using PSA as shown at Figure 1. Nanosilica with particle size of $330 \mathrm{~nm}$ could still be incorporated in the nano-order defined by Namazi et al.(2012) as dispersed particles or solid particles having sizes in the range of 10-1000 nm. Uniformity of particle size was said to be good if the PDI value gets smaller. Nanoparticles having a PDI value greater than 0.7 should not be used in the application, whereas if the PDI value in the range 0.5-0.7 was still within the tolerance limit for application usage (Setiyawati, 2015).

Based on XRD analysis, nanosilica had crystalite size of $47.49 \mathrm{~nm}$ and crystallinity degree of $64 \%$.Precipitation process in the synthesis of nanosilika produces particles that had a tendencyto form amorphous. 
Table 1. The elements contained in boiler ash and furnace ash

\begin{tabular}{clcc}
\hline No & Element & $\begin{array}{c}\text { Boiler ash } \\
(\%)\end{array}$ & $\begin{array}{c}\text { Furnace ash } \\
(\%)\end{array}$ \\
\hline 1 & $\mathrm{Si}$ & 57.4 & 56 \\
2 & $\mathrm{Fe}$ & 29.3 & 32 \\
3 & $\mathrm{Al}$ & 8.20 & 6.80 \\
4 & $\mathrm{Ti}$ & 3.13 & 3.34 \\
5 & $\mathrm{Mn}$ & 1.52 & 1.64 \\
6 & $\mathrm{Zr}$ & 0.13 & 0.21 \\
7 & $\mathrm{Zn}$ & 0.13 & 0.16 \\
8 & $\mathrm{Cu}$ & 0.04 & 0.07 \\
9 & $\mathrm{Ni}$ & 0.03 & 0.05 \\
10 & $\mathrm{Cr}$ & 0.05 & 0.01 \\
\hline
\end{tabular}

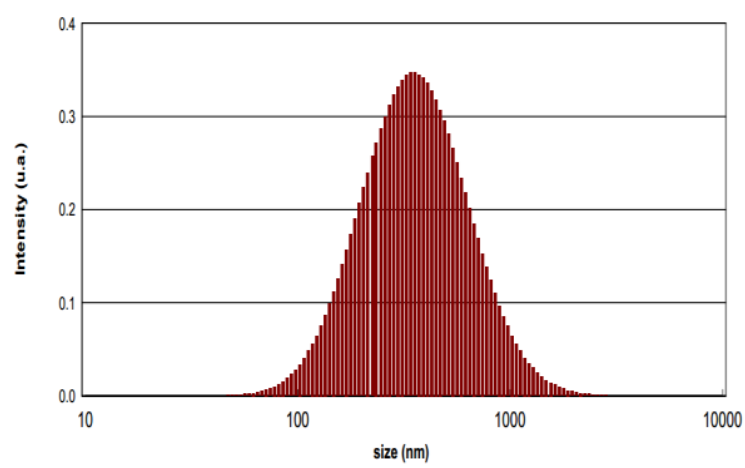

Figure 1. Particle size and PDI of nanosilica

Ismayana (2014) notified that the process of hydrolysis-precipitation of silica particles to nanosilica should reduce the degree of crystallinity to $54.57 \%$ from $76.34 \%$. The cracking on structure of chemical bonds in the silica via hydrolysis process caused the crystal structure became irregular and the arrangement of particles became more amorphous. Decreasing the degree of crystallinity would increase the hydrophilic properties of the material (Iolevich, 2014).

It was mentioned by Utomo (2015) that when $\mathrm{pH} 7$ and 3-hour aging time produced the lowest degree of crystallinity and produced more silanol (hydrophilic) groups. The higher hydrophilic group on the composite could increase the transfer of protons in the electrolyte membrane (Dewi 2008), so the nanosilica would be suitable for additives to membranes for DMFC.

\section{Sulfonation Degree of sPEEK}

Sulfonation degree indicated the presence of sulfonate groups in PEEK.Polymer sulfonation was a method for inserting sulfonic acid groups into the polymer structure. Sulfonation was done in order to reduce the rigidity of the membrane caused by the main constituent compounds. The presence of a sulfonate group in the polymer chain made the polymer more hydrophilic in that it facilitated the transport of protons in the membrane (Zaidi 2003). The sulfonation of PEEK with concentrated $\mathrm{H}_{2} \mathrm{SO}_{4}(95-97 \%)$ at $60^{\circ} \mathrm{C}$ resulted sPEEK with sulfonation degree of $75 \%$. The presence of sulfonate group also proved by FTIR analysis that showed the appareance of peak at wave number of $1227.21 \mathrm{~cm}^{-1}$. According to Pramonoet al., (2012), the sulfonate group was marked by the appearance of a peak at the wave numberof $1200-1300 \mathrm{~cm}^{-1}$. Sulfonation degree affectedthe hydrophilicity of polymer. It increased the characteristic of electrolyte membrane.The greaterof sulfonation degree would increase water and methanol absorption, ion exchange capacity, and proton conductivity.

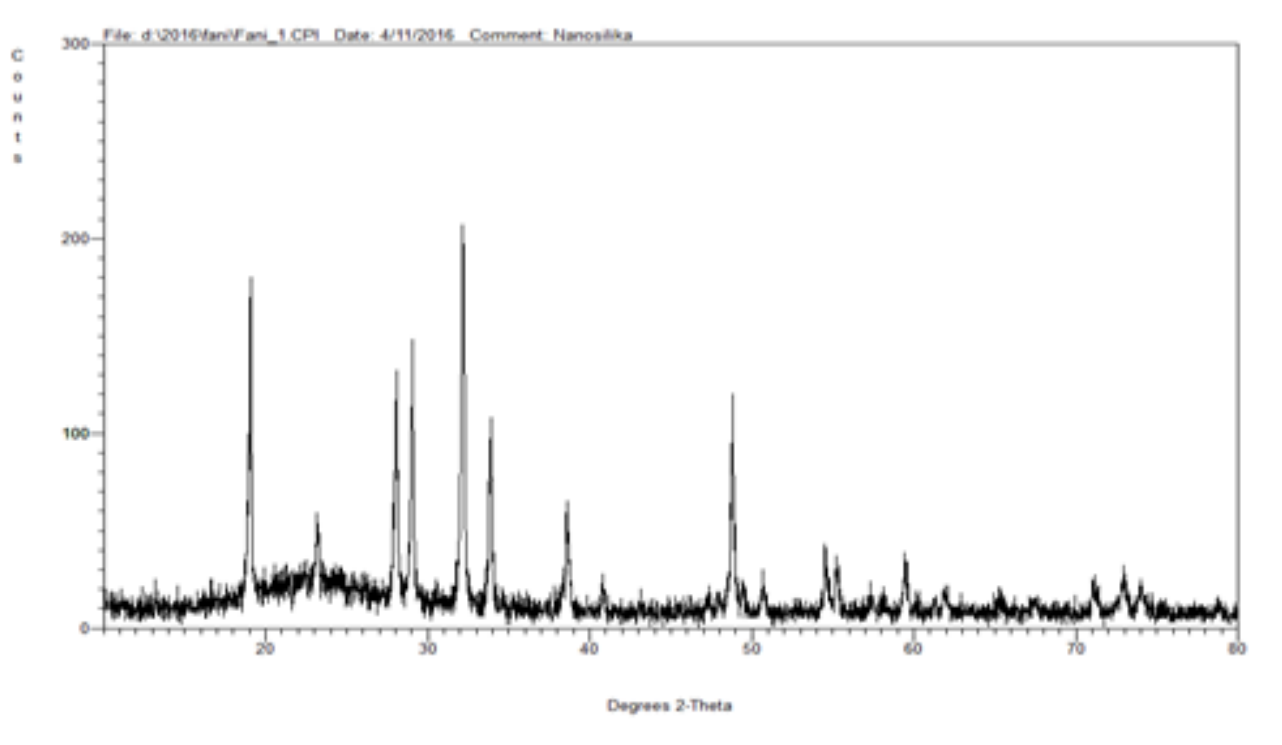

Figure 2. Diffractogram of nanosilica 


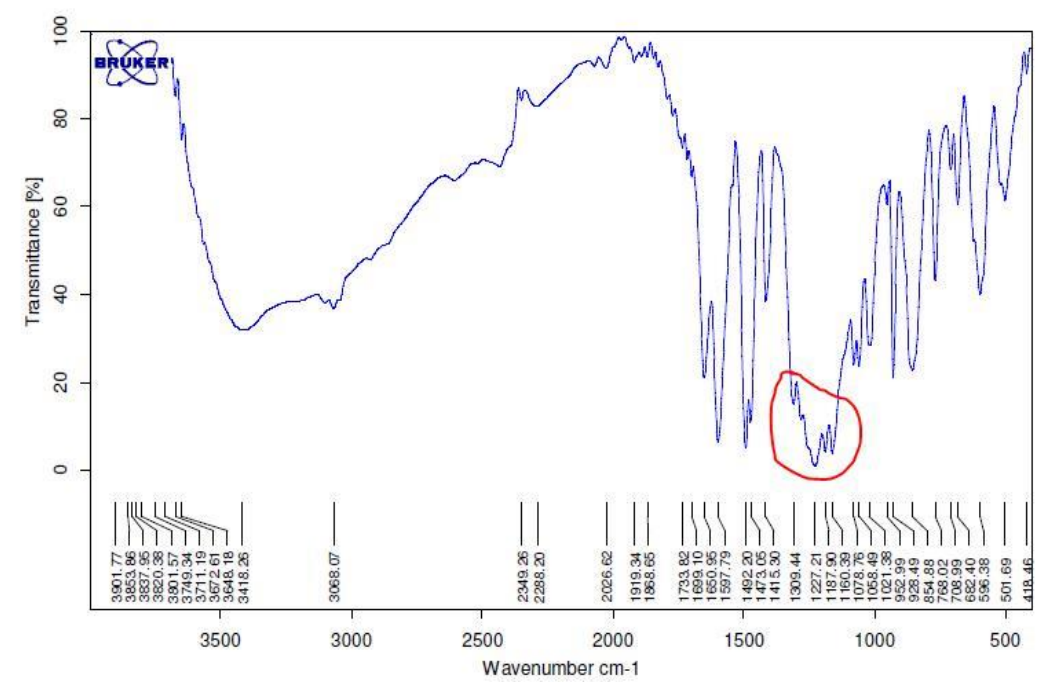

Figure 3. The resultf of FTIR test of sPeek

\section{Membrane Characteristics Water Absorption}

The conductivity of the DMFC membrane depended on the amount of acidic group and the dissociation of in water. The presence of water and acidic groups would facilitate the transport of protons, therefore the nature of water uptake was an important parameter for DMFC membrane. The ability of the membrane to absorb water had a correlation with ionic conductivity and mechanical stability (Handayani et al., 2007). The water presence of the DMFC membrane serves as a proton transport medium $\left(\mathrm{H}^{+}\right)$. The higher water absorption could increase the membrane's ability to transfer protons (ion conductivity values). However if the value is too high, the water absorption membrane will reduce the mechanical properties of the membrane causing damage to the membrane (Handayaniet al., 2007). Figure 4 represents the value of water absorption in membranes.

Figure 4 stated that there is an effect of increasing the water absorption of membranes when added nanosilica. This was reinforced by the analysis of varriance that the presence of nanosilica significantly affect the level of 0.05 . The silica clusters contained four oxygen atoms, which readily reacted with water because of the silanol group $(\equiv \mathrm{Si}$ $\mathrm{OH})$ whichis acidic, so that the silica easily absorbed water (Handayani, 2008).

Silica had a very good hygroscopic and absorb more water if it had filled the pores of the membrane. When nanosilica concentration increased above $3 \%$, water absorption tended to decline (Figure 4). This decrease could be caused by the addition of too much nanosilica would cover the sulfonate group on the membrane, so the membrane hydrophilicity propertiesdecreased (Hartanto et al., 2007). In addition, the addition of too much nanosilica should also cause agglomeration between nanosilicaparticles so that nanosilica could not spread evenly. This could reduce the surface area of hydrophilic nanosilica that would eventually decrease the membrane's ability to absorb water.

Although there was a change when the addition nanosilica, but the value of water absorption membranes still qualified as an electrolyte membrane (less than 30\%). The highest water absorption was owned by $3 \%$ nanosilica and blending composition of PSF-sPEEK (1:12). Addition of $3 \%$ of nanosilica was the right value because the composition of the additive was able to cover the pores or gaps in the membrane (Hartanto et al., 2007).

\section{Methanol Absorption}

The higher absorption of methanol caused the higher of permeability of methanol. Methanol permeability or methanol crossover occured when methanol moves from the cathode side to the anode. Methanol permeability was not desirable in DMFC applications because it could decrease the performance of DMFC cell voltage (Hartanto et al., 2007). Observations results on methanol absorption were shown in Figure 5.

Figure 5 indicated the effect of increased methanol absorption when added by nanosilica. This was reinforced by the analysis of varriance that the presence of nanosilica significantly affected the level of 0.05 . Membrane with variation of blending composition and addition of amount of nanosilica had the value of absorption of methanol which significantly different from each other $(\alpha=0.05)$. The highest absorption of methanol owned by $3 \%$ nanosilika and blending composition (Psf:sPEEK) $1: 12$. The addition of nanosilica above $3 \%$ results in a decrease in the absorption of methanol, which was caused by the excess of nanosilica particles that filled the membrane pore, thus inhibiting the penetration of methanol into the membrane. 


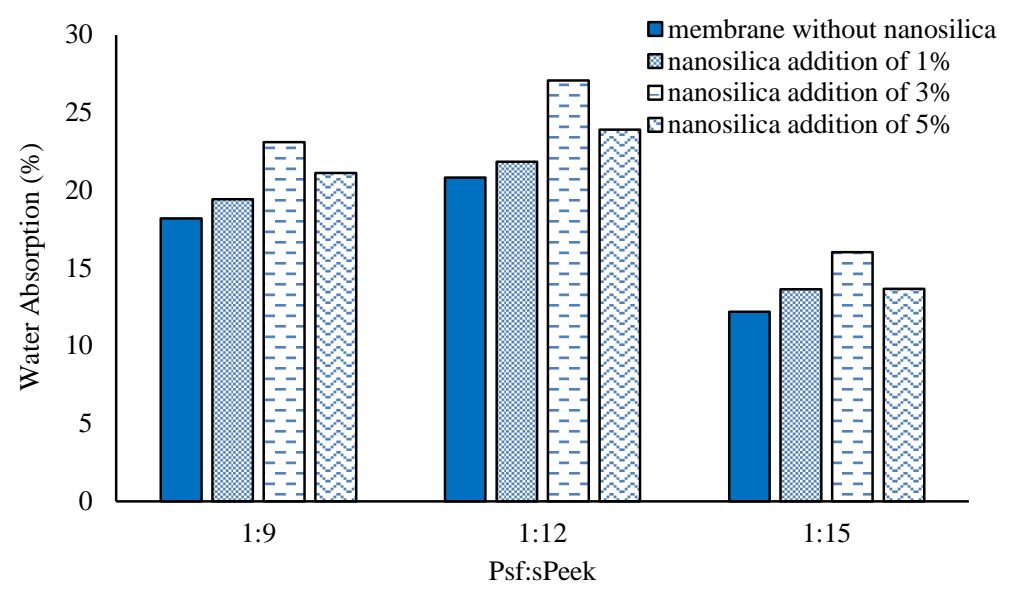

Figure 4. Water absorption of membranes

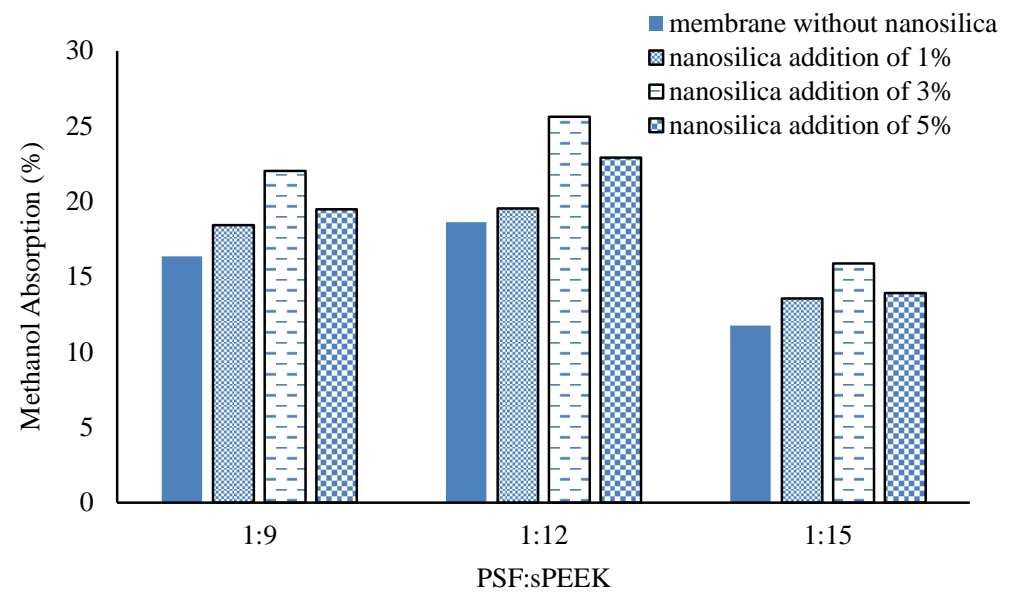

Figure 5. The value of methanol absorption

The membrane's ability to absorb methanol was influenced by the properties of membrane polymers having hydrophilic groups so as to bind polar groups in methanol. The increased surface area of composites and interactions would impact on the compact density of the membrane structure thus preventing the occurrence of methanol crossover.

Ion exchange capacity (IEC) was a parameter that indicates the ability to perform a proton exchange membrane $\left(\mathrm{H}^{+}\right.$ions). The higher water absorption will facilitate in providing the membrane proton transport medium for water which serves as a transport medium so that the proton conductivity is too high. The value of IECwas shownat Figure 6 (a) and the value of ion conductivity was shownat Figure 6 (b).

Figure 6 a showed that there was an effect of increasing the ion exchange capacity when added nanosilica. The presence of $\mathrm{SiO}_{2}$ groups in the membrane would increase the ion exchange capacity, since $\mathrm{SiO}_{2}$ would ionize to form $\mathrm{Si}_{4}{ }^{+}$ions and should increase the membrane ion exchange rate. While Figure $6 \mathrm{~b}$ had shown that there was an effect of increasing ion conductivity when added the nanosilica.Annova test resulted that the presence of nanosilica significantly affected the level of 0.05 . The ionic conductivity affected the transfer of negative ions which would be converted into positive ions. Where more water was absorbed the more ions should be channeled to be converted into positive ions

The highest value of IEC and ion conductivity was obtained by membrane with PSF:sPEEK ratio of 1:12 andnanosilica addition of $3 \%$. The addition of nanosilica until concentration of $3 \%$ could improve the conductivity of the membrane, while the conductivity of the membrane tends to decrease when the addition of nanosilica more than $3 \%$. Silicic acid will be formed by the addition of excess silica. The acid caused the ionization of $\mathrm{H}^{+}$decreased so its impact on the lower ion conductivity. In addition, the closure of sulfonate groups by nanosilica decreased the membrane ability to absorb water, so that the proton transfer media on the membrane would decrease which impact on the decrease of IEC (Hartanto et al., 2007). 


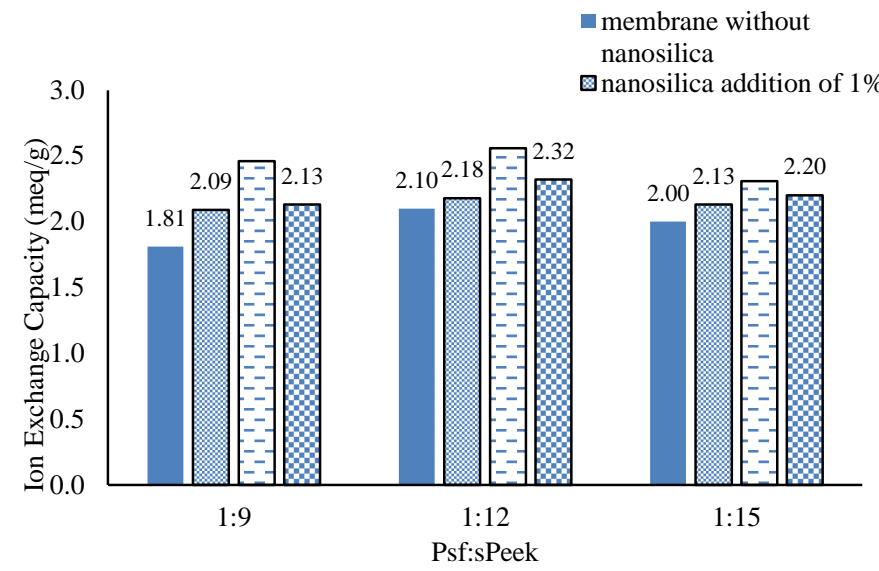

(a)

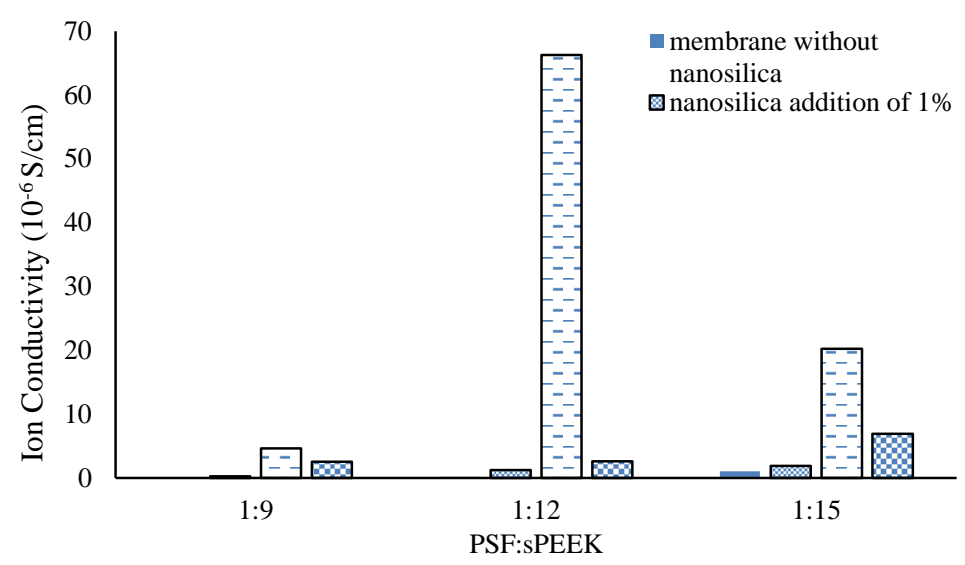

(b)

Figure 6. The value ofion exchange capacity (a), ion conductivity (b)

The PSF:sPEEK composition of 1:12 resulted the highest value of IEC and ion conductivity because the fraction of SPEEK was much higher than PSF. The higher fraction of sPEEK increased the ability membrane to transport proton as sPEEK was more acidic and hydrophilic than PSF.

\section{Membrane Functional Groups}

Membrane PSF-sPEEK with nanosilica addition contained several functional groups. According to Pramonoet al., (2012), sulfonate group $\left(\mathrm{SO}_{3} \mathrm{H}\right)$ was characterized by appearance of a peak at the wave number of $1200-1300 \mathrm{~cm}^{-1}$. Sulfonate group $\left(-\mathrm{SO}_{3} \mathrm{H}\right)$ was characterized by the appearance of a peak at the wave number of $1229 \mathrm{~cm}^{-1}$. The $\mathrm{OH}$ group was identified at wave number of $3430 \mathrm{~cm}^{-1}$. Functional group of siloxane (Si-O-Si) was identified in the wave number of $1100 \mathrm{~cm}^{-1}$ (Sukaet al., 2010). Silanol (Si-O) grup was identified at wave number of $972.26 \mathrm{~cm}^{-1}$. Sulfonate group and silanol group resulted hydrophilicmembrane, so it was easy to absorb water as a proton transfer medium. Media of proton transfer would increase proton transfer from anode to cathode, andresulted theincrease of ion conductivity of the membrane.
The functional groups identified in PSF-sPEEK of $1: 12$ and $3 \%$ of nanosilica membrane according to FTIR analyzed was shown at Figure 7.

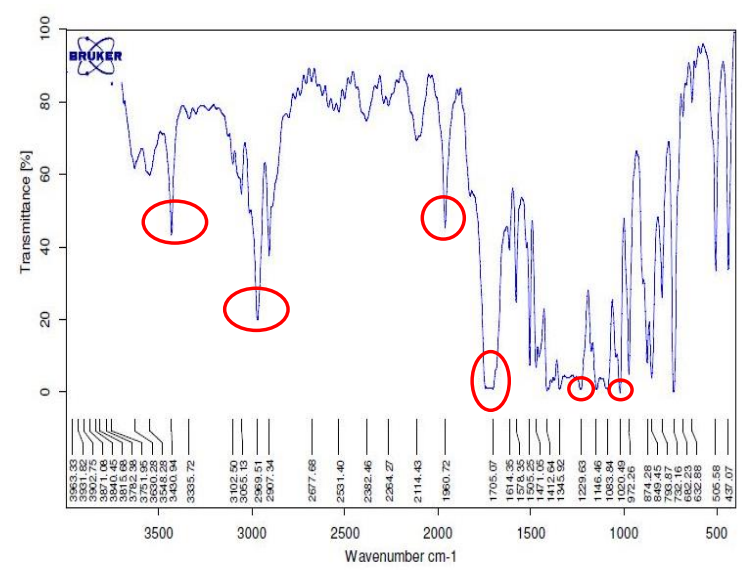

Figure 7. Functional groups of (Psf:sPeek) + nanosilica $((1: 12)+3 \%)$ membrane 
Tabel 2. Functional groups of PSF:sPEEK+nanosilica (1:12+3\%) membrane

\begin{tabular}{cll}
\hline No & \multicolumn{1}{c}{ Groups } & $\begin{array}{c}\text { Wave number } \\
\left(\mathbf{c m}^{-1}\right)\end{array}$ \\
\hline 1 & OH group & 3430 \\
2 & Vibration of simetric oxygen sulphur O=S=O & 1079.51 \\
3 & Sulfonic acid & 1345.92 \\
4 & Ether aromatic & 1960.72 \\
5 & Sulfonate group & 1229.63 \\
6 & CH aromatic chain & 3069.39 \\
7 & Aromatic ketone carbonil & 1705.07 \\
8 & Para-benzen substitution & 1614.35 \\
9 & Si-O & 972.26 \\
\hline
\end{tabular}

\section{CONCLUSIONS AND RECOMMENDATIONS}

\section{Conclusions}

Synthesis of nanosilicafromboiler ash sugarcane industry by using alkaline extraction and precipitation process could be used as a filler in the manufacture of electrolytic membranes for DMFC. The addition of nanosilicaincreased the membrane performance, especially the ion conductivity. The addition of $3 \%$ nanosilica and theratio of PSFsPEEK 1:12 were the optimum composition in this research due to the highest performance of water absorption, methanol absorption, ion exchange capacity, and ion conductivity. The PSFsPEEK+nanosilica membrane was potential to be applied for DMFC system.

\section{Recommendations}

This research need further test for methanol permeability and application to DMFC system. Membrane performance also can be improved by modifying the membrane thickness, variation of time, and temperature sulfonation of SPEEK.

\section{ACKNOWLEDGEMENTS}

This research was supported by General Directory of Strengthening Research and Development from Ministry of Research, Technology, and Higher Education Republic of Indonesia through the Grant of Competence.

\section{REFFERENCES}

Adam F, Thiam-Seng C, and Andas J. 2011. A simple template-free sol-gel synthesis of spherical nanosilica from agricultural biomass. Journal Sol-Gel Science Technology 59:580-583.

Bossel U. 2000. The birth of the fuel cell. European fuel cell forum: oberrohrdorf
Carettel Friedrich KA, and Stimming U. 2001. Fuel Cell Fundam and Appl. Wiley Online Library.

Dupont. 1996. Nafion®, technical information data sheet, globalcustomerservice.DuPont Fuel Cells. DuPont ${ }^{\mathrm{TM}}$ Nafion ${ }^{\circledR}$ PFSA Membranes NE-1135, NE-115, NE-117, NE-1110 Datasheet.

Handayani S, Purwanti WW, Dewi EL, Singgih H, Soemantojo RW. 2007. Blending polisulfon dengan poli eter-eter keton tersulfonasi untuk sel bahan bakar metanol langsung. Jurnal Teknik. 21(2): 158-164.

Handayani S. 2008. Membran elektrolit berbasis polieter-eter keton tersulfonasi untuk direct methanol fuel cell suhu tinggi [Disertasi]. Jakarta: University of Indonesia.

Hartanto S, Handayani S, Marlina L, Latifah. 2007. The effect of $\mathrm{SiO}_{2}$ on electrolyte membrane base polyether ether keton. India Journal of Mat Sci. 8 (3): 205-208.

Ismayana A, Maddu A, Sailah I, Mafquh E, Indrasti NS. 2017. Synthesis of nanosilica from boiler ash of sugar cane industry with ultrasonication method and addition of surfactant. Jurnal Teknologi Industri Pertanian. 27 (2): 228-234.

Juniarzadinata R. 2011. Kajian struktur dan uji fluksmembranpolisulfondenganmetodeinversi fasa [Thesis]. Bogor: Bogor Agricultural University.

Namazi H, Fathi F, dan Heydari A. 2012. Nanoparticles Based On Modified Polysaccharides. Iran : In Tech.

Pramono E, Wicaksono A, Priyadi, Wulansari J. 2012. Pengaruh derajat sulfonasi terhadap degradasi termal polistirenater sulfonasi. Ind Journal of Appllied Physics. 2(2):157.

Qisti N, Indrasti NS, dan Suprihatin. 2017. Optimization of process condition of nanosilica production by hydrothermal method. Mat Sci and Eng. 162 (2017): 1-9.

Setiawan WK, Indrasti NS, dan Suprihatin. 2015. Synthesis and characterization of nanosilica 
from boiler ash with co-precipitation method. Proceeding of International Conference of Adaptive and Intelligent Agroindustry (ICAIA) 2015. Bogor, Indonesia, 3-4 August 2015.

Setiawan WK. 2015. Preparation of nanosilica from boiler ash by co-precipitation method as additive for electrolyte membrane based chitosan. [Thesis]. Bogor: Bogor Agricultural University.

Suka IW, Simanjuntak W, dan Listiani DE. 2010. Pembuatan membran polimer elektrolit berbasis polistirenakrilonitril (san) untuk aplikasi direct methanol fuel cell. Journal Natur Ind. 13(1):1-6.
Thuadaij N dan Nuntiya A. 2008. Preparation of nanosilica powder from rice husk ash by precipitation method. Chiang Mai Journal Science. 35(1):206-211.

Utomo SS. 2015. Synthesis and characterization nanosilica from boiler ash sugar cane industry with aging time and precipitation $\mathrm{pH}$ variation. [Thesis]. Bogor: Bogor Agricultural University. 